\title{
An Examination on Performance of Railway Sleepers
}

\author{
Suresh Kumar A, Muthukannan M
}

\begin{abstract}
The main focus of railways is of all economies, transporting items, and passengers. The important role of sleepers is the performance of track and rail transport safety. In sleeper manufacturing, different kinds of materials (Timber, Concrete, and Steel) are utilized. The most widely used sleeper material is Hardwood Timber. The demand for sleepers will move on lots better side in time to come back due to the failures of the Sleepers. The production and maintenance cost of the sleeper is higher. This paper discusses the different failures of classic concrete, steel, and timber sleepers and the capacity of defensive action to minimize those failures. This paper comprehensively evaluates with the recommended solutions for the three typically used sleeper materials of its failure mechanisms. In order to make cost-effective sleeper, the waste materials from industries can be used as supplementary raw material with a purpose to result in enhancing the great for the environment as properly. For the approaching years, every production activity needs to focus on sustainable engineering and this study tries to present the alternative smart solution for the destiny infrastructure engineering region.
\end{abstract}

Keywords: Railway Sleepers, Failure of Sleepers, Alternative Materials, Minimise Failure

\section{INTRODUCTION}

A railway is a backbone for the development of all economies by providing means of transporting goods and passengers. A common man can go to different parts of the country with low price in railways. In India, the components of the railway track system gone through the slow development from the timber sleepers to concrete sleepers. Day by day the usages of railways are increased. For improving the rail service, enhance the trip frequency and improve the load carrying capacity [1]. In later years, there was a growing assignment in railway engineering studies. Railway tracks have been designed based totally on attention to overcome the heavier load-carrying capacity of the roads and trucks either for the time being or within the destiny. Usually, ballasted railway track which includes rails, sleepers, ballast formation, and fastening systems is proudly built for transportation in particular in a remote area.

Revised Manuscript Received on December 05, 2019.

* Correspondence Author

Suresh Kumar A*, Department of Civil Engineering, Kalasalingam Academy of Research and Education, Virudhunagar, India. Email: sureshalmighty@gmail.com

Muthukannan M, Department of Civil Engineering, Kalasalingam Academy of Research and Education, Virudhunagar, India. Email: civilkannan@gmail.com
The railway sleepers play an essential position in transferring and distributing loads uniformly from the rail to ballast to guide the rail firmly and evenly, hold the gauge of the track effectively, to behave as an elastic medium between the rail and the ballast and to take in the vibration of the trains and to align the rail properly. There is a number of sleeper production units in our country. The demandfor sleepers will go on a lot better aspect in time to return. In the near future, the railways are probable to broaden as a minimum 5000 to 8000 kilometer of rail network per year, which is almost 30 to $40 \%$ extra than in past, assuming that kilometer of rail would need 1600 sleepers these plans are probable to outcomes in annual demand of about 1.3 crores of sleeper. Present manufacturing cost of monoblock broad gauge pre-stressed concrete sleeper is within the range of 2200 - 2500/-. The cement which is applied for the manufacture of the sleeper is the main raw material [2].A worldwide survey was conducted by the International Federation for Structural Concrete [3] for conventional sleepers in the world's railway network for annual demands and mentioned in Table 1.

Table- I: Demand of Sleepers in Railway Network throughout the World

\begin{tabular}{|c|c|c|c|c|}
\hline \multirow[t]{2}{*}{ Country name } & \multirow{2}{*}{$\begin{array}{l}\text { Track with number } \\
\text { of Sleepers }(x \text { 1000) }\end{array}$} & \multicolumn{3}{|c|}{$\begin{array}{l}\text { Sleepers Demand per year } \\
(x \text { 1000) }\end{array}$} \\
\hline & & Timber & Concrete & Steel \\
\hline Australia & 600000 & 200 & - & 150 \\
\hline USA & 600000 & 13000 & 1000 & 10 \\
\hline India & 163500 & - & 4640 & - \\
\hline Russia & 150000 & - & 3500 & - \\
\hline China & 115000 & - & 3000 & - \\
\hline Germany & 70000 & 100 & 1400 & 100 \\
\hline France & 60000 & 400 & 800 & 0 \\
\hline Brazil & 50000 & 300 & 500 & 60 \\
\hline UK & 45000 & 100 & 500 & 400 \\
\hline South Africa & 43000 & 0 & 305 & 0 \\
\hline Italy & 40000 & - & 2000 & - \\
\hline Japan & 34000 & - & 400 & - \\
\hline Spain & 30000 & 30 & 1200 & 0 \\
\hline Hungary & 20388 & - & - & - \\
\hline Sweden & 19500 & 8 & 400 & - \\
\hline Crezh Rep. & 17000 & 3 & 250 & - \\
\hline Switzerland & 17000 & - & 150 & - \\
\hline Romania & 16000 & - & 12 & - \\
\hline Belgium & 9912 & 20 & 400 & 2 \\
\hline Austria & 9000 & 100 & 200 & 70 \\
\hline Netherlands & 8500 & - & 400 & - \\
\hline Greece & 6150 & 3 & 30 & 5 \\
\hline Chile & 5300 & - & 200 & - \\
\hline Colombia & 5080 & - & - & - \\
\hline Morroco & 5000 & - & - & - \\
\hline Taiwan & 4000 & 12 & 120 & 0 \\
\hline Malaysia & 3000 & - & & - \\
\hline
\end{tabular}




\begin{tabular}{|l|l|l|l|l|}
\hline Norway & 3000 & - & 60 & - \\
\hline Venezuela & 1225 & - & - & - \\
\hline Argentina & - & - & 60 & - \\
\hline Denmark & - & - & 150 & - \\
\hline
\end{tabular}

This survey illustrates that in many countries concrete superior material for sleeper except the USA in which the timber sleeper has the primary demand. It's far envisioned that in the railway networks throughout the world has approximately 3 billion sleepers are there. In that, more than 400 million concrete sleepers are there and due to premature failure of sleepers $2-5 \%$ of the required replacement every year [4]. This papers intention is to present the failure mechanisms of the sleepers and give some suggestions to minimizethe failure of thesleeper and to make cost-effective and green sleepers by using alternate construction materials.

\section{MATERIALS FOR RAILWAY SLEEPERS}

The most commonly used is Timber Sleepers (Fig. 1), these days the usage of pre-stressed concrete sleepers (Fig. 2) and steel sleepers (Fig. 3) are increased. The merits and demerits of materials used for the railway are mentioned inside the following Table 2 [1].

Table- II: Merits and Demerits of Materials used for Railway

\begin{tabular}{|c|c|c|c|}
\hline & Timber Sleeper & Concrete Sleeper & $\begin{array}{l}\text { Steel } \\
\text { Sleeper }\end{array}$ \\
\hline Types & $\begin{array}{l}\text { Hardwood (sal) } \\
\text { Chir } \\
\text { Softwood } \\
\text { (Deodar) }\end{array}$ & $\begin{array}{l}\text { Monoblock pre- } \\
\text { stressed concrete } \\
\text { sleepers } \\
\text { Twinblock sleepers }\end{array}$ & $\begin{array}{l}\text { Y-shaped } \\
\text { steel } \\
\text { sleeper }\end{array}$ \\
\hline $\begin{array}{l}\text { Manufacturing } \\
\text { cost }\end{array}$ & Low & High & $\begin{array}{l}\text { Less than a } \\
\text { concrete } \\
\text { sleeper }\end{array}$ \\
\hline Merits & $\begin{array}{l}\text { Workable } \\
\text { Easy to handle } \\
\text { Easy to replace }\end{array}$ & $\begin{array}{l}\text { Longer life cycle } \\
\text { Lower maintenance } \\
\text { cost } \\
\text { Stability at high } \\
\text { speeds }\end{array}$ & $\begin{array}{l}\text { Easy to } \\
\text { handle } \\
\text { Life span } \\
\text { is more } \\
\text { Free from } \\
\text { fire hazard }\end{array}$ \\
\hline Demerits & $\begin{array}{l}\text { Mechanical and } \\
\text { Biological } \\
\text { degradation }\end{array}$ & $\begin{array}{l}\text { Transport } \\
\text { Laying } \\
\text { Maintenance requires } \\
\text { superior technology }\end{array}$ & $\begin{array}{l}\text { Corrode } \\
\text { easily }\end{array}$ \\
\hline Treatment & $\begin{array}{l}\text { Softwood sleepers } \\
\text { soaked in coal tar } \\
\text { creosote }\end{array}$ & - & - \\
\hline Scrap value & Less & No & More \\
\hline
\end{tabular}

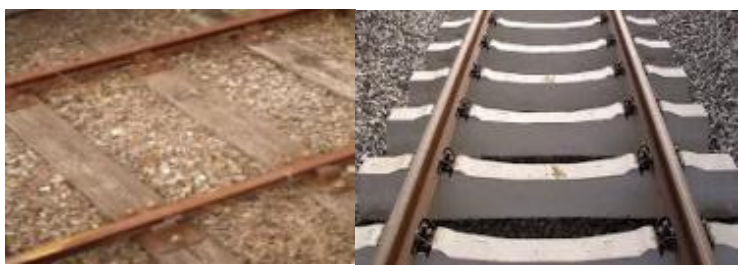

Fig. 1. Timber Sleepers Fig. 2. Concrete Sleepers

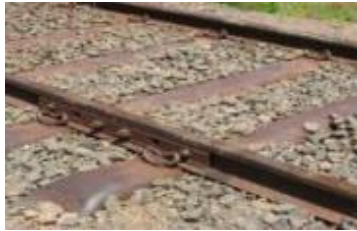

Fig. 3. Steel Sleepers

\section{FAILURE OF SLEEPERS}

The failure of sleepers was reviewed in 2014 [5] and in this section the detail of the failures are explained.

\section{A. Failures of Timber Sleeper}

It is necessary to minimize the maintenance value of the track and to enhance the track performance by acceptable examination for the source of untimely failures of sleepers The Railway of Australia (ROA) [6] surveyed several states in Australia to be able to understand the reasons and mode of timber sleeper failure. For this cause, in Queensland railway tracks nearly 2200 timber sleepers were tested and discovered various causes for harming the sleeper is inclusive of decomposing due to fungus, splitting at the ends, termite attacks, still sound, sapwood, shelling, rail cut, weathering, spike kill and knots (Fig. 4). In this, decompose due to fungus $(53 \%)$, splitting at the ends $(10 \%)$ and termite attacks $(7 \%)$ have been determined to be the main reasons for the timber sleeper failure.

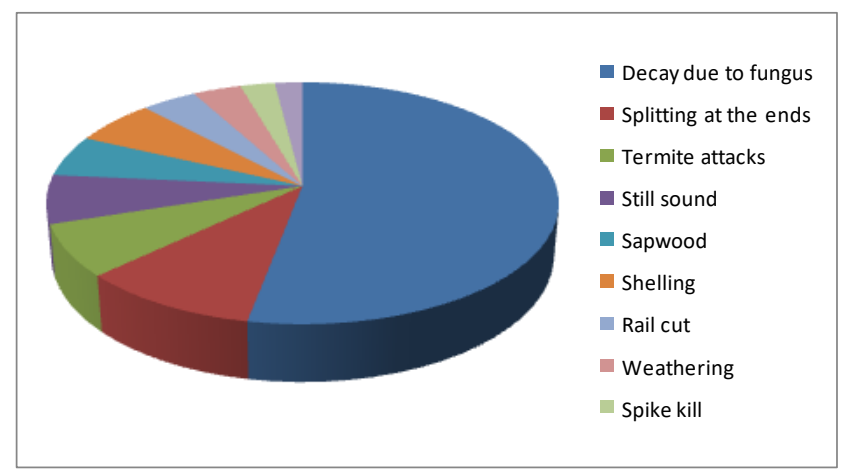

Fig. 4. Common causes of Failures in Timber Sleeper

- Decompose due to fungus: Timber is a natural material, so it is prone tomany plagues to biodeterioration. Decompose due to fungus is the primary mode of failure in timber sleeper. In timber, a fungus can be prone reposing till it gets appropriate surroundings carrying $\mathrm{H}_{2} \mathrm{O}, \mathrm{O}_{2}$, and nutrients. Particularly in rainy seasons, railway sleepers can take in moisture, and it will make fungus active and if it present in timber, it can affect the integrity of track's structure by spreading from one sleeper to every other throughout nonnutritional surfaces $[7,8]$. The decompose due to the fungus of a timber sleeper (Fig. 5).



Fig. 5.Decompose due to fungus (9)

- Splitting at the ends:When the sleepers are under a huge transverse shear loading timber sleeper is failed by splitting at its $[9,10]$. Additionally, an acceptable fastening device which includes screw-spike, sleeper plate and a rail fastening clip is attached to the rails in every sleeper.

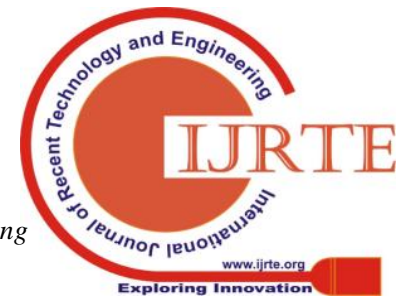


Splitting at the ends in sleeper due to screw-spike insertion (Fig. 6).

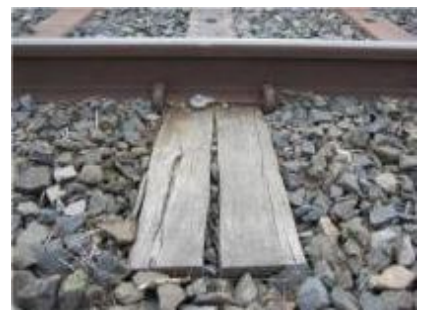

Fig. 3. Splitting at the ends (9)

- Termite Attack: Another considerable cause of timber sleeper damage is termite attacks and it has been suggested that the global value is approximately 1 billion dollars yearly for repairing structures and preventing these attack [11]. When the timber is attacked by termites, it swallows all materials containing cellulose and damages the sleeper permanently [12]. Sleepers, after treated with creosote, invasions of termites, were located in (Fig. 7).



Fig. 7. Attack by Termites [13]

\section{B. Failures of Concrete Sleeper}

In the 1950's the sleepers are prepared by the concrete for many advantages. These days, in the international's railway networks approximately 500 million railway sleepers are made from pre-stressed concrete. Every 12 months, the request for pre-stressed concrete sleepers comprise extra than $50 \%$ of a general demand [3,4]. In 1970, Monoblock pre-stressed concrete sleepers are started using as a sleeper and in Australia, the large part of the latest railway sleepers are made of pre-stressed concrete sleepers [14]. The results from the North American and global surveys [15] are received and ranked the maximum usual reasons for failures in concrete sleeper (Fig. 8). The result specified that the crucial source of concrete sleeper failure is rail seat deterioration within North America and the installation or tamping harm globally. But, from country to country the mode of failures may vary.

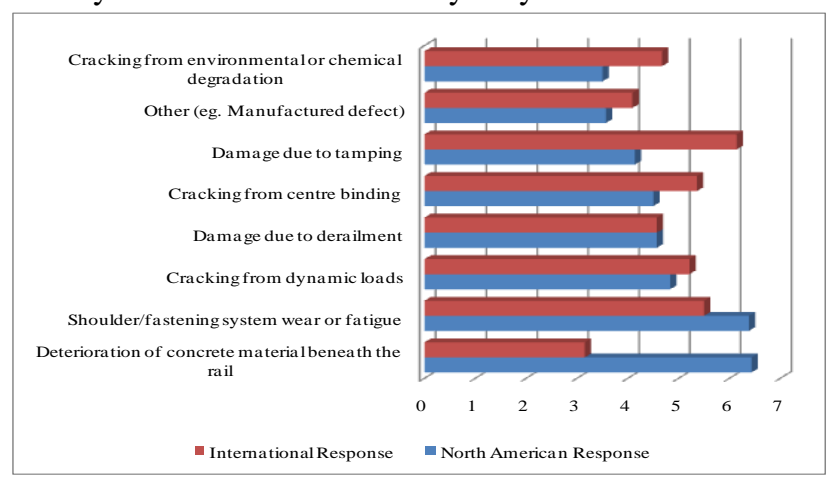

Fig. 8. Concrete Sleeper Failures [15]
- Rail seat deterioration: The failure in the rail seat is the most common mode of failure in modern concrete sleepers all over the world. The failure of rail seat is mainly produced either by freeze-thaw cracking, chemical deterioration, hydraulic pressure cracking, rail seat abrasion, and hydro-abrasive erosion [16] of this rail seat abrasion is the most critical one. The mechanism of rail seat abrasion was investigated $[17,18]$ and found that a shear force is acting on the rail pad when the wheel load is transferred from the pad to the sleeper through the rail. If the shear force exceeds fatigue limit of the concrete also exceed and the deterioration will start. A number of things are liable for rail seat abrasion, including heavy axle loads, shoulder or sleeper pads, failure of fasteners, presence of water and track curves greater than $2^{\circ}[19,20]$. In 2010 [21], the hydraulic pressure cracking failure was investigated and results showed that the high pressure is responsible for rail seat deterioration. (Fig. 9) indicates Abrasion of rail seat region.

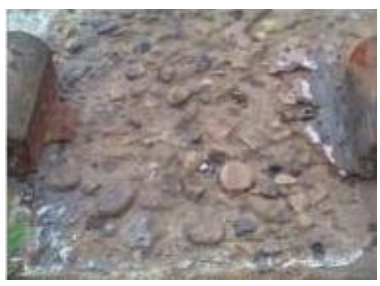

Fig. 9. Rail seat abrasion [22]

- Derailment:The primary causes of the derailment failure are existing impermissible defects in track and manpower fault. The track maintenance cost is increased for replacing the damaged sleepers due to the derailment. In 2012 [23], located that in Iranian railways B70 concrete sleepers have derailment disasters (Fig. 10).



Fig. 10. Derailment of Concrete Sleepers [23]

- High-impact loading:The flexural stiffness of the sleeper is reduced by the bending cracks at the midspan of concrete sleeper. During field inspection lots of cracks have been observed in concrete sleepers, the main cause identified is infrequent but in short duration high magnitude wheel load [24,25]. Present design recommendations are based totally on the most effective loading situations of static and quasi-static and do not recollect the excessive value of the impact load. (Fig 11) showing a crack due to impact loading on the sleepers. (Fig. 12a) illustrates the railway sleeper collapse and (Fig. 12b) the conditions of the joint in the repaired track. The investigational research conducted [26] and decided that the failure of sleeper under impact loading (Fig. 13a). A comparable non-performance sample changed into finding for the duration of an area investigated which verified 
failure of sleeper under impact loading (Fig. 13b).

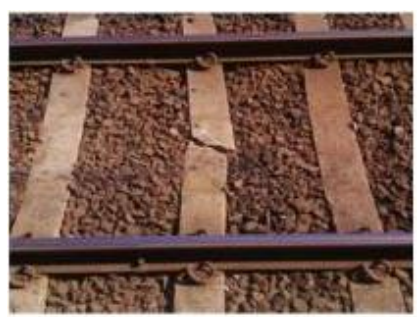

(a) cracks at centre of sleeper

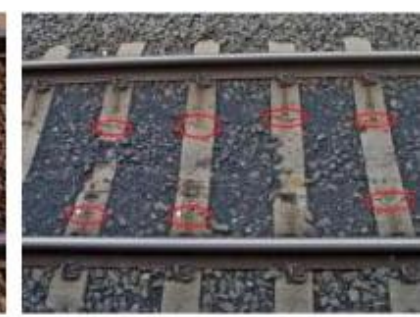

(b) cracks near location of sleepers' rail seats
Fig.11. Cracks due to impact loading in concrete sleepers $[27,28]$

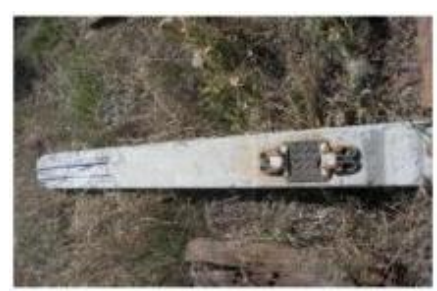

(a) collapsed sleeper



(b) sleeper after track maintenance
Fig.12. Impact damage due to rail irregularities to sleeper [30]

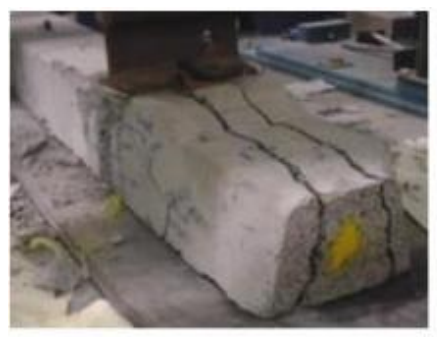

(a) experimental failure mode

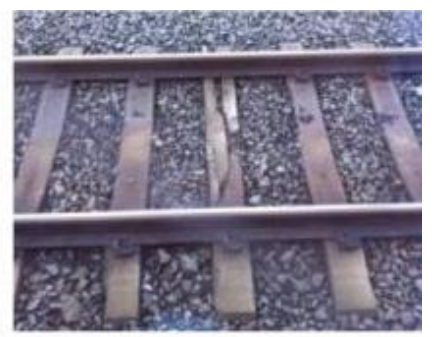

(b) field investigation
Fig. 13. Splitting failure caused by impact loading in concrete sleeper [26]

- Center-bound damage:In a mainline railway track, concrete sleeper. They observed a tensile fracture on the top of the sleeper (Fig. 14a) which spread the cracks after the expecting duration of its crucial phase and " $\mathrm{X}$ " shape fracturing is formed clearly (Fig. 14b). A new study [30] located that a sleeper installed in the railway track before the service has failed by longitudinal cracking (Fig. 15a). During service, a further outcome like freezing of water and fine rocks existing in rawlplugs will cause longitudinal cracks (Fig. 15b). The same conclusions have been given [31] who determined that the principle purpose of longitudinal cracks in a sleeper is due to the excessive shearing tensile stress at bolt hole edge.

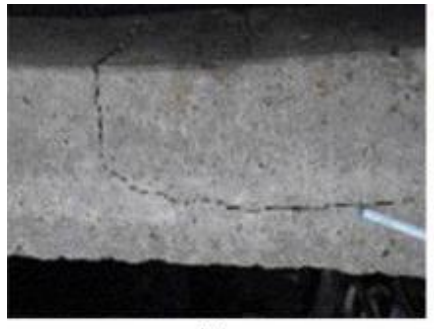

(a)

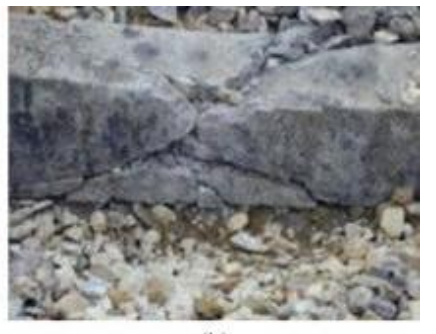

(b)
Fig. 14. Tensile fracture in concrete sleeper [32] the tensile fracture may occur on the pre-stressed



(a) before service

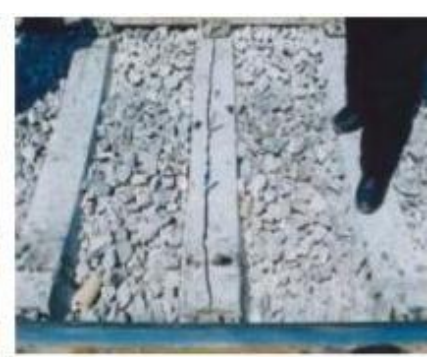

(b) during service
Fig. 15.Longitudinal cracking between rawlplugs [30].

- Acid Attack:The strong acids will easily attack the concretes that are made from OPC [33] and when hydrates in cement come into contact with the acids then $\mathrm{CA}(\mathrm{OH})_{2}$ will convert into salts with more calcium [34,35]. Also, acids can attack calcium aluminate hydrate and calcium silicate hydrate $(\mathrm{C}-\mathrm{S}-\mathrm{H})[33,35]$ and the effect of acid attack (Fig. 16). The main source of acid rain is the emission of the huge amount of $\mathrm{SO}_{2}$ and nitrogen oxide into the environment.

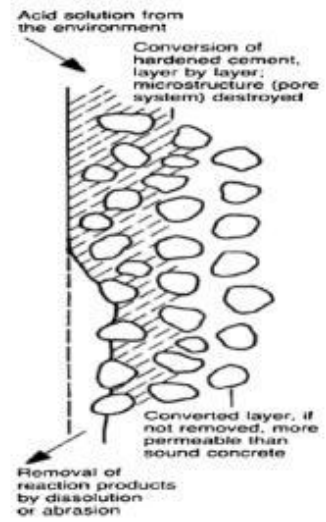

Fig. 16.Effect of acid attack [35].

- Alkali-Aggregate Reaction (AAR):The reactive substance in the cement and in the aggregates is the main difference between sulphate and alkali attacks [35]. Despite the fact is that Ordinary Portland Cement (OPC) is the main supply of alkalis in concrete, on occasion, a further one is an unwashed fine aggregate containing sodium chloride and combining water is also taken into consideration inner resources [33]. (Fig. 17) Effects of AAR

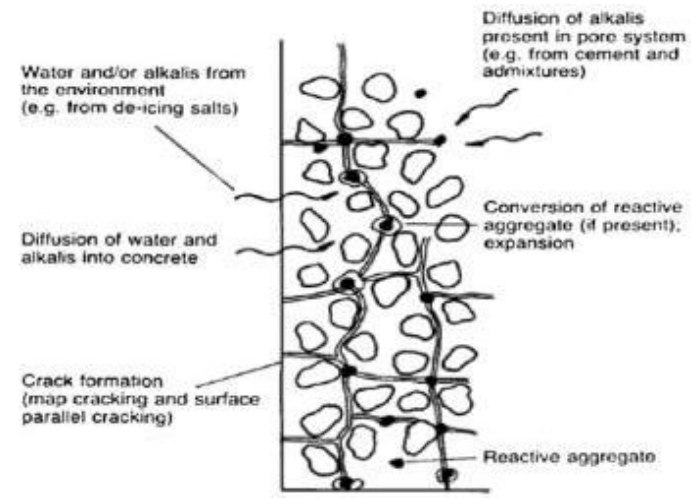

Fig. 17. Effect of AAR [35]

The AAR is liable for sleeper failures due to the reasons of parallel longitudinal cracking at the top surfaces and maps cracking at the ends of pre-stressed concrete sleepers [36]. This was




also diagnosed by using any other investigation in China [37] investigated an affected concrete sleeper in the Shanghai area and via its (SEM/EDAX) analysis the crack is formed in the concrete sleeper due to the presence of reactive silica. (Fig. 18) AAR failure in a sleeper.



Fig. 18.Cracking due to AAR in concrete sleeper [38].

- $(D E F)$ - Delayed Ettringite Formation:The deterioration of concrete is occurred by cracking. If the aggregate, soil, and groundwater contain sulfates of magnesium, calcium, sodium, and potassium. In solution, if sulfates are presented, then it will react with the calcium hydroxide and tricalcium aluminate. This reaction causes expansion and it leads to cracking $[33,34]$ as depicted in (Fig. 19).

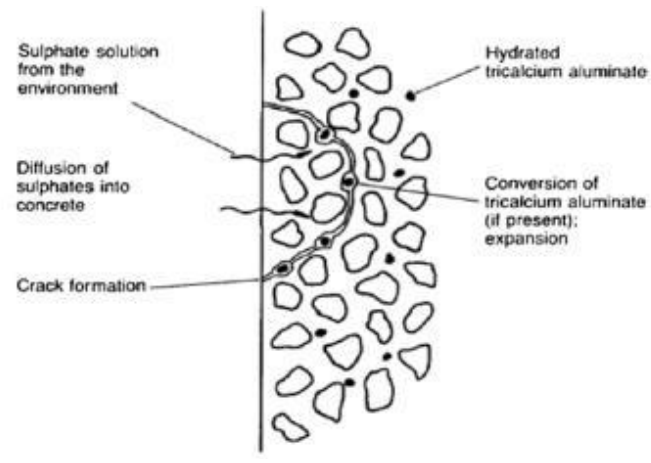

Fig. 19.Effect of sulphate attack [35].

The concrete sleeper can deteriorate by DEF because of internal sulphate attack. The earliest commentary of it become stated [39], that the concrete sleepers are damaged within 10 years from its manufacture due to microcrack formation in the course of the pre-casting process in Finland. Additionally, at steam-curing temperatures fewer than $75^{\circ} \mathrm{C}$ even if the systems take $16 \mathrm{~h}$ the failure because of DEF not occurred [40]. The cracking of pre-stressed concrete sleepers due to DEF might also come once they were in service for several years [41] (Fig. 20). Similarly, untimely failure occurs because of DEF in a Swedish concrete sleeper in 7 years after its manufacture [42].



Fig. 20.Cracking due to DEF in pre-stressed concrete sleeper [41].

\section{Failures of Steel Sleeper}

A small number of researches have been conducted for the failure of steel sleepers. However, numerous investigators detailed that the steel has risk in corrosion; rail seat region is cracking due to fatigue, high conductivity of electricity and the problem of packing it with ballast.

- Corrosion in Steel:When the ballast or soil is supported in high salinity area, the corrosion will take place in steel sleepers. Both rail and sleepers are made from steel, still, sleepers have high risk in corrosion due to direct contact with the subgrade materials and ballast. (Fig. 21) Corrosion failure in steel sleeper. The further causes for the steel sleeper to corrode are if the ballast is based on steel slag, continuous moist surroundings [43].

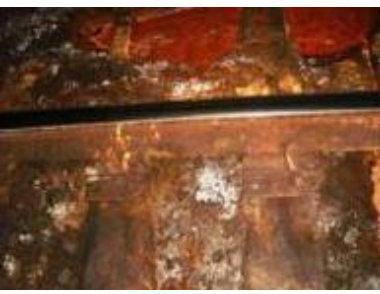

Fig. 21.Corrosion in steel sleeper [44].

\section{APPROACHES TO MINIMIZE SLEEPER FAILURE}

The aim of many researchers is to reduce the issues in railway sleepers. Already a number of them have been applied. A few investigators have targeted on taking responsibility of conventional sleepers even as others have brought notably recent material. In this part, the most suitable approach and great practice for reducing the failure of a sleeper and it's maintenance work are discussed.

\section{A. Timber Sleeper}

If some of the remedial measures are taken to the conventional timber sleepers, it can be safe from the untimely failure. As a consequence, many researchers have advised some techniques to save timber sleeper failure.

- Decompose due to fungus and attack due to termites:The safety procedures in timber structure are quite similar for controlling fungus and termite attack [45], and recent time, the most common technique used is soaked with synthetic chemicals and biological prevention have been studied by many researchers. The harmful organisms in timber can be destroyed by some toxic chemicals. These chemicals were used for more than 200 years because the cost is very low. The application of chemical preservatives and disposal of the timber sleeper have becomea big concern for environmental agencies [46]. Lately, it had been emphasizing the usage of chemicals used to protect the timber by biological protection techniques that deal with public worries and it conforms with new environmental policies $[45,47]$. The loss of dignity of timber can be controlled by biological as actual as chemical prevention and environmental safety is one of the additional benefits. (Fig. 22) diagrammatic illustration of 
measures to control termite in timber structures.

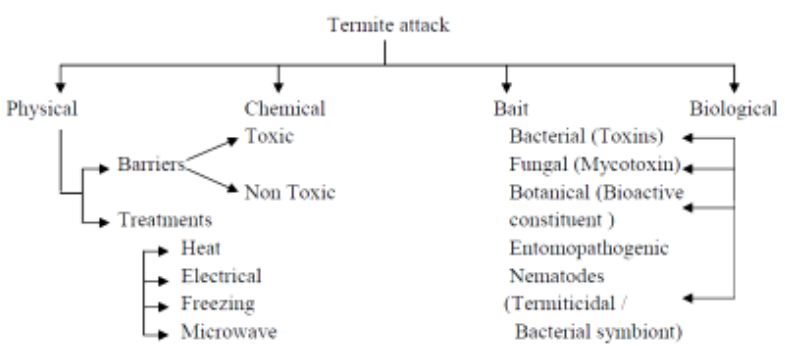

Fig. 22.Measures to control termites

- Control of end splitting: The timber splitting at the ends can be controlled by fixing a plate at its end $[8,48]$. This method is applicable when the width is less than $20 \mathrm{~mm}$ and length not more than $250 \mathrm{~mm}$. The limits accepted for splitting for seasoned and unseasoned sleepers are width $6 \mathrm{~mm}$ and $3 \mathrm{~mm}$ for $100 \mathrm{~mm}$ long. Consequently, the sleepers beyond the accepted limit but width not more than $20 \mathrm{~mm}$ and length $250 \mathrm{~mm}$, by using end plates it can be saved. (Fig. 23a) saveable and (Fig. 23b) non-saveable timber sleeper.



(a) end-plate is effective



(b) could not be saved by end-platic
Fig. 23. End-splitting failure minimization technique [8]

\section{B. Concrete Sleeper}

The most essential failure mode of sleepers made of concrete is rail seat deterioration and cracks in concrete. These types of failures can be minimized and arrested by numerous methods and in this section, it is discussed.

- Preventing abrasion in rail seat:In North America, the most critical problem for concrete sleeper is due to rail seat deterioration. Numerous researches have concentrated on minimizing and arresting these failures. In 2003 [49], attempted by using the plates made of steel to cover the area of rail seat to minimize abrasion. There is no rail seat abrasion occurred when the experimental program of fatigue testing completed, which ran 10 million cycles at a rate of 2.5 cycles/sec (Fig. 24). However, the cost of the manufacturing sleeper is increased for additional steel plates and the water presented below the concrete will lead to deterioration in the rail seat region. While adopting this approach, the above issue should be carefully considered. Coating with Epoxy over the area of rail seat is another approach to prevent abrasion [50]. However, wearing of epoxy, epoxy curing required more labour and during the application, the track should be closed because of these reasons this method is not a convincing one. The researchers have considered some different preventive methods are: in the rail seat area the concrete with silica fume and fly ash [51]. During manufacturing, steel fiber reinforced grout introduced in the area of rail seat
$[49,52]$. In rail seat area placing of metallic aggregates [53]. In 2002 [54], Abrasion-resistance properties are more in High volume fly ash concrete and the areas where highly abrasion-resistant is required High volume fly ash concrete is suggested. However, the compressive and tensile strength of the concrete in the rail seat area can be increased by adding some materials to concrete [19,51].

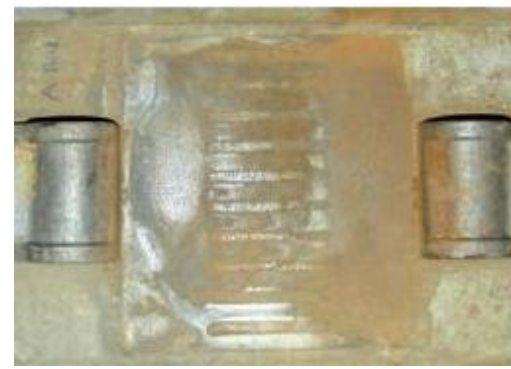

Fig. 24.Rail seat covered by a steel plate after 10 million cycles [49].

- Control of longitudinal crack: The main reason for longitudinal cracks is due to the excessive shearing tensile stress around the bolt hole/ rawlplug. To minimize the shearing tensile stress [31] by using a special concrete within the inner part and normal concrete at the outer part of the bolt-hole region. The alternative method to reduce longitudinal crack is by changing the direction of crack and cracking planes by placing a transverse reinforced bar to strengthen the sleeper transversely and to induce pressure around the rawlplug hole [30].

\section{Steel Sleeper}

To minimize the problems in steel sleeper only limited studies have been conducted. For controlling steel corrosion some recommendations are given by researchers, one of them the Australian Rail Track Corporation (ARTC) has suggested that steel sleepers usage should be avoided in the places where saltiness is high, wet regions, slag ballast, and regions with corrosive materials, including clay, mud, dirt, minerals, and coal [50]. The presence of salt is harmful to the steel which will speed up corrosion and as per ARTC steel sleepers should be avoided in the place of high salinity [51]. ARTC also recommended that the corrosion can be protected over the steel by Zinc coating. The Transit Cooperative Research Program (TCRP) disclosed that the ballast with the steel slags will enhance corrosion in steel and steel sleepers with slag ballast for the railroad tracks are not recommended [55].

\section{NEED OF NEW MATERIAL}

Concrete, the raw material is easily available, the preparation is very simple and it can be moulded into various shapes because of its advantages it is most widely used construction material around the world. Portland cement is one of the essential elements in an ordinary concrete mix. However current literature discloses that approximately $5 \%$ of $\mathrm{CO}_{2}$ emission throughout the world comes from the cement industry. By 2050 the demand and production of




cement worldwide will be increasing from 2836 million tons to a maximum of 4380 million tons. For the production of 1 ton Portland cement, the required raw materials is 1.5 tons and releasing of $\mathrm{CO}_{2}$ to the surrounding is nearly 1 ton. OPC was used as the main construction material, even though it has too many environmental problems while the production process [56]. Because of the population increase and the need for new structures the global intake of concrete increases. In concrete, except cement all the ingredients are natural. Therefore there is a requirement in developing an alternative construction material. Now scientist and engineers have to develop analternative binding material to replace cement. The requirement of the new materials is it should be with less environmental impact and durability. Developing alternative construction material is necessary for the future.

\section{DISCUSSION}

In this review, the main problems in timber sleeper are their vulnerability to mechanical and biological degradation, together with Decompose due to fungus, Splitting at the ends and Attack due to termites which leads to its failure. The majority sleepers in railway are made of mono-block pre-stressed concrete sleepers because of their extra durability in the destructive environment. The fundamental problems in these types of sleepers are vulnerability to chemical attack [DEF, AAR and many others] and low impact resistance. Then again the stressful issue related to steel sleeper is due to the fatigue cracking on the region of rail seat which causes its deterioration. The acceptance of steel sleeper is decreased due to corrosion risk and different chemical attacks. Researchers have investigated some of the reduction strategies to protect the sleepers from their destructive conditions. The healing counts mentioned above are effective to guard sleepers against its pretimely failure. However, the price related to it is a remarkable concern. But, research and improvement at the moment are focussed on recently developed materials for sleeper manufacturing, which have the more capable to remedy plenty of issues in conventional timber, concrete, and steel sleeper.

\section{CONCLUSION}

Alkali-Aggregate Reaction (AAR) and Delayed Ettringite Formation (DEF) are the main modes of concrete sleeper failure. It can be minimized by changing cement with Industrial waste cementitious materials, which will give extremely good engineering properties like protection against chemical degradation. Then again it gives high impact loading, corrosion resistance, durability, and fatigue lead them to green sleeper material. More studies required on these new materials which can be used as mainline railway sleepers because it is more economical. For installation, repair and maintenance less labour are required. The amount of energy and producing $\mathrm{CO}_{2}$ will be minimized. A large quantity of waste material can be changed into productive use when composite materials are used. Destructive of the forest will be less by adopting composite sleepers. The properties of composite sleepers are similar to the traditional sleeper.PrestressedGeopolymer Concrete is the best solution to solve the above problems. It is made of aluminosilicate as a source material with alkaline
solution.Railway produces around 1.3 crore sleepers each year and if they use industrial waste in concrete for sleepers, it's going to reduce the value of manufacturing of each sleeper by approximately Rs 30, with the intention to imply a typical value saving of Rs 30 to 35 crore in keeping with annum for India Railways. This review paper highlights that the reuse of Industrial waste cementitious material can deal with the disposal problem and also it will make a resource for production with economical units in transportation engineering.

\section{REFERENCES}

1. Abhishek Budhavant, Priyanka Danane, Shreyas Joshi, Dr.ShantiniBokil. Latest Trends and Technologies for Railway Engineering Using Composite Sleepers. International Journal of Engineering Research in Mechanical and Civil Engineering 2018.

2. Ashish Paliwal, Vinay Deulkar, Dr. Sunil Sugandhi. A Review on Cost Effective Railway Sleeper. International Journal for Scientific Research \& Development 2018

3. International Federation for Structural Concrete. fib Bulletin 37: Precast concrete railway track systems, state-of-art report; 2006.

4. Palomo A, Jiménez AF, Hombrados CL, Lleyda JL. Railway sleepers made of alkali-activated fly ash concrete. Revista Ingeniería de Construcción 2007;22:75-80.

5. Wahid Ferdous, Allan Manalo. Failures of mainline railway sleepers and suggested remedies - Review of current practice. Engineering Failure Analysis 44 (2014) 17-35

6. Hagaman BR, McAlpine RJA. ROA timber sleeper development project. In: Conference on railway engineering: demand management of assets. ACT, Barton, Australia: Institution of Engineers; 1991. p. 233-237.

7. Singh J. Dry rot and other wood-destroying fungi: their occurrence, biology, pathology and control. Indoor Built Environ 1999;8: 3-20.

8. Conners T. Producing and inspecting railroad crossties. Department of Forestry, University of Kentucky - College of Agriculture; 2008.

9. Manalo A, Aravinthan T, Karunasena W, Ticoalu A. A review of alternative materials for replacing existing timber sleepers. Compos Struct 2010;92:603-611.

10. Hibbeler RC. Statics and mechanics of materials. SI ed. Singapore: Prentice Hall; 2004.

11. Ahmed BM, French JRJ. Report and recommendations of the National Termite Workshop, Melbourne, 17 April 2002. Int Biodeter Biodegr 2005;56:69-74

12. Horwood M, Eldridge R. Termites in New South Wales: Part 2. Termite infestations: inspection, detection and treatment. For Resour Res 2005;22.

13. Operation full stop 2003: stopping the swarm. Agricultural Research Magazine.U.S. Department of Agriculture, Science and Education Administration; 2003. p. 4-8.

14. Kaewunruen $\mathrm{S}$. Track design fundamentals, rail engineering course, rail corporation. Sleepers Fastenings 2010

15. Dyk BJV, Dersch MS, Edwards JR. United States Department of Transportation (US DOT), Federal Railroad Administration (FRA) Washington DC, USA: International concrete crosstie and fastening system survey; 2012.

16. Bakharev T, Struble LJ. Microstructural features of rail seat deterioration in concrete ties. J Mater Civil Eng 1997;9:146-153.

17. Zeman JC, Edwards JR, Barkan CPL, Lange DA. Failure mode and effect analysis of concrete ties in North America. In: 9th International heavy haul conference: heavy haul and innovation development Shanghai, China, 22-25 June 2009. p. 270-277.

18. Kernes RG, Edwards JR, Dersch MS, Lange DA, Barkan CPL Investigation of the dynamic frictional properties of a concrete crosstie rail seat and pad and its effect on rail seat deterioration (RSD) Transportation Research Board 91st Annual Meeting; 2011.

19. Lutch RH, Harris DK, Ahlborn TM. Causes and preventative methods for rail seat abrasion in North America's railroads. Cold Regions Eng 2009:455-466.

20. Ma C, Zhang X, Li X. Cause and prevention practice of rail seat abrasion of concrete ties. In: 2nd International conference on civil 
engineering, China. 16-18 December 2011. p. 561-564.

21. Zeman JC, Edwards JR, Lange DA, Barkan CPL. Evaluating the potential for damaging hydraulic pressure in the concrete tie rail seat. ASME 2010 Joint Rail Conference, United States, vol. 1. 27-29 April 2010. p. 349-358.

22. Zeman JC, Edwards JR, Lange DA, Barkan CPL. Investigation of potential concrete tie rail seat deterioration mechanisms: cavitation erosion and hydraulic pressure cracking. Transportation Research Board 89th Annual Meeting; 2009

23. Zakeri JA, Rezvani FH. Failures of railway concrete sleepers during service life. Int J Constr Eng Manage 2012;1:1-5.

24. Murray M, Cai Z. Australasian Railway Association, Inc. Pre-stressed concrete sleepers - literature review. December 1998.

25. Remennikov AM, Kaewunruen S. Resistance of railway concrete sleepers to impact loading. In: 7th International conference on shock \& impact loads on structures Beijing, China. October 17-19; 2007. p. 489-496.

26. Kaewunruen S, Remennikov AM. Experiments into impact behaviour of railway pre-stressed concrete sleepers. Eng Failure Anal 2011;18:2305-2315.

27. UK railway forums/Infrastructure \& station/Broken sleeper http://i225.photobucket.com/albums/dd281/ainsworth74/Rail/Photo0001.jpg; 15 January 2014.

28. Kaewunruen S, Remennikov AM. Effect of a large asymmetrical wheel burden on flexural response and failure of railway concrete sleepers in track systems. Eng Failure Anal 2008;15:1065-1075.

29. Kaewunruen S, Remennikov AM. Dynamic flexural influence on a railway concrete sleeper in track system due to a single wheel impact. Eng Failure Anal 2009;16:705-712.

30. Rezaie F, Shiri MR, Farnam SM. Experimental and numerical studies of longitudinal crack control for pre-stressed concrete sleepers. Eng Failure Anal 2012;26:21-30.

31. Ma C, Li X, Bu J. Cause and modification measures of longitudinal cracks from bolt hole of the PC sleepers II. In: Tenth international conference of Chinese transportation professionals (ICCTP), Beijing, China. 4-8 August 2010.

32. González-Nicieza C, Álvarez-Fernández MI, Menéndez-Díaz A, Álvarez-Vigil AE, Ariznavarreta-Fernández F. Failure analysis of concrete sleepers in heavy haul railway tracks. Eng Failure Anal 2008;15:90-117.

33. Neville AM. Properties of concrete. England: Longman Scientific \& Technical; 2012. [34] Narayanan RS, Beeby AW. Designers' Guide to EN 1992-1-1 and EN 1992-1-2. Eurocode 2: design of concrete structures. General rules and rules for buildings and structural fire design. Thomas Telford Ltd.; 2005.

34. Kaewunruen S, Remennikov AM. Experiments into impact behaviour of railway prestressed concrete sleepers. Eng Failure Anal 2011;18:2305-15.

35. Durable concrete structures: design guide by Comite EuroInternational Du Beton. Thomas Telford; 1992.

36. Shayan A, Quick GW. Microscopic features of cracked and uncracked concrete railway sleepers. Mater J 1992;89:348-361.

37. Qinhua J, Min D, Sufen H. Investigation of deteriorated concrete railway ties. Cem Concr Res 1996;26:999-1006.

38. Fournier B, Bérubé MA, Thomas MDA, Smaoui N, Folliard KJ. Evaluation and management of concrete structures affected by alkalisilica reaction - a review. In: Seventh CANMET/ACI international conference on recent advances in concrete technology. Farmington Hills, Michigan; 2004

39. Tepponen P, Eriksson BE. Damages in concrete railway sleepers in Finland. Nordic Concr Res 1987:199-209.

40. Heinz D, Ludwig U. Mechanism of subsequent ettringite formations in mortars and concretes after heat treatment. In: 8th International Congress on chemistry of cement Rio De Janeiro; 1986. p. 189-194.

41. Hime WG. Delayed ettringite formation - a concern for precast concrete? PCI J 1996:26-30.

42. Sahu S, Thaulow N. Delayed ettringite formation in Swedish concrete railroad ties. Cem Concr Res 2004;34:1675-1681.

43. ARTC. Steel sleepers - usage and installation standards TCS 10 Engineering (Track) Australian Rail Track Corporation, 2009.

44. Hernandez FCR, Koch K, Barrera GP. Transit Cooperative Research Program. Transportation Research Board. Contractor's Final Report for TCRP Project D-7. Task 14 Rail base corrosion detection and prevention; 2007.
45. Verma M, Sharma S, Prasad R. Biological alternatives for termite control: a review. Int Biodeter Biodegr. 2009;63:959-972.

46. Thierfelder T, Sandström E. The creosote content of used railway crossties as compared with European stipulations for hazardous waste. Sci Total Environ 2008;402:106-112.

47. Susi P, Aktuganov G, Himanen J, Korpela T. Biological control of wood decompose against fungal infection. $\mathrm{J}$ Environ Manage 2011;92:1681-1689.

48. ARTC. Timber sleeper and turnout specification, ETA-02-01 Engineering (Track \& Civil) Standard, Australian Rail Track Corporation; 2011.

49. Peters N, Mattson SR. CN 60E concrete tie development. In: AREMA conference proc. Landover, Maryland; 2004.

50. Peters SR. J.A. Cesare \& Associates Inc: 8. Abrasion testing of epoxycoated concrete ties (using symons product No. 301 epoxy); 2007.

51. Shurpali AA, Kernes RG, Edwards, Dersch MS, Lange DA, Barkan CPL. Investigation of the mechanics of rail seat deterioration (RSD) and methods to improve the abrasion resistance of concrete sleeper rail seats. In: 10th International heavy haul association conference, New Delhi, India. 4-6 February 2013.

52. Takahashi T, Sekine E, Horiike T, Matsuoka S, Hoshiro H. Study on the applicability of short fibre reinforced concrete to precast concrete slabs for slab track. Quart Report RTRI 2008;49:40-46.

53. Wu K, Yan A, Yao W, Zhang D. Effect of metallic aggregate on strength and fracture properties of HPC. Cem Concr Res 2001;31:113118.

54. Atis CD. High volume fly ash abrasion resistant concrete. J Mater Civil Eng 2002;14:274-277.

55. TCRP report 155: Track design handbook for light rail transit. 2nd ed Washington, DC: National Academy of Sciences; 2012.

56. Mehta, PK 1999, 'Concrete technology for sustainable development', Concrete International - Detroit -, vol. 21, pp. 47-53.

\section{AUTHORS PROFILE}

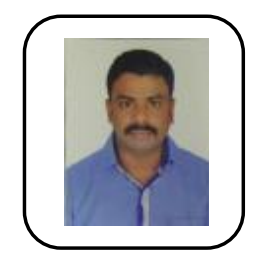

Mr. Suresh Kumar.A is currently doing full time $\mathrm{PhD}$ in Department of Civil Engineering from Kalasalingam Academy of Research and Education, Krishnankoil, India. He completed his Bachelor degree in Civil Engineering from Raja College of Engineering and Technology, affiliated to Anna University, Chennai. He completed his Master of Engineering in Structural Engineering fromMepcoSchlenk Engineering College affiliated to Anna University, Thirunelveli. His areas of interest are Concrete Technology, new alternative materials, eco-friendly materials and Prestressed Concrete.

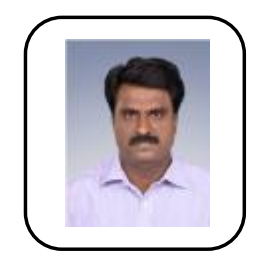

Dr.Muthukannan M completed his Ph.D in Civil Engineering in Anna University, Chennai in the year 2010. He completed Master of Engineering in the field of Transportation Engineering and Management in College of Engineering, Guindy, Chennai in the year 2004. He completed his Bachelor of Engineering under Madurai Kamarajar University in the year 2000. He is presently working as a Professor in Civil Engineering department at Kalasalingam University, Tamilnadu, India. He is guiding for many Ph.D scholars in the field of transporation engineering and Geopolymer Technology. He has published various quality papers in the reputed journals. His main thrust research areas are Geopolymer technology, transportation network design, transport management and travel demand management. 